\title{
THE PUNISHMENT OF MURDERERS IN THE NOBLE COURTS OF THE GRAND DUCHY OF LITHUANIA IN THE SECOND HALF OF THE 18TH CENTURY ${ }^{1}$
}

\author{
Adam Stankevič \\ (Lithuanian Institute of History)
}

\begin{abstract}
This article gives an analysis of the punishment the noble courts of the Grand Duchy of Lithuania applied to murderers in the second half of the 18th century, where the noble courts acted as courts of first instance in hearing murder cases. The author aims to determine the catalogue of punishments applied in such cases and the trends in the application of punishments in terms of how they conformed with the valid legal norms of the day, and search for manifestations of the humanisation of the law. After an examination of 184 verdicts, the author found that in cases of wilful murder, the noble courts usually applied the death penalty as per the set laws. Exceptions applied only to individuals from the estate of nobles, who instead of receiving a death sentence were sometimes sentenced to lower or upper tower punishment, which was by law ordinarily applied to other crimes. At the same time, the executors avoided qualified ways of applying the death sentence (capital punishment). Of the qualified forms of punishment, only quartering was applied, usually to those convicted of the aforementioned crime, ritual murder, and, in some instances, in cases of robbery. Alternative forms of punishment were episodic, and were only applied to a small number of convicted persons: imprisonment as a form of punishment recommended by philosophers of the Age of Enlightenment was applied in only 5.3 per cent of murder cases. In most instances, imprisonment was related to the introduction of the 1782 Cardinal Laws of the Permanent Council. In this way, the research reveals the conservative nature of the estate of nobles in the Grand Duchy of Lithuania, and their efforts to continue to adhere to the strict law outlined in the Third Statute of Lithuania. It is likely that this practice could have been a result of the poor state of the penitentiary system, as there was not a single public prison in the Grand Duchy of Lithuania at the time where long-term imprisonment could have been possible.
\end{abstract}

KEYWORDS: criminal law, Grand Duchy of Lithuania, the Third Statute of Lithuania, murder cases, punishment.

${ }^{1}$ The article was written as part of the Research Council of Lithuania's 'Support for PhD students' internship programme 'Murders in the Grand Duchy of Lithuania in the Second Half of the 18th Century (Legal and Social Aspects)', financed through 'Developing Competency among Scientists, other Researchers and Students through Practical Scientific Activities'. Contract No 09·3·3-LMT-K-712-02-0o84. 


\section{Introduction}

Rapid changes were taking place in the Polish-Lithuanian state in the second half of the 18th century, which also affected the legal sphere: this was a time when certain ideas of philosophers of the Age of Enlightenment started being implemented. ${ }^{2}$ Most efforts went towards the reform of the courts, by which a whole series of changes were introduced: the structure of the courts was changed, a new election procedure for judges was determined, the competency of the courts was defined in greater detail, and the activities of the courts, judges and court chancellery were regulated. ${ }^{3}$ However, the changes also applied to the area of criminal law, and procedures that were probably the main objects of criticism from members of the 'humanist' movement in Western Europe. In their works, philosophers attacked the aims of criminal repressions, and the very principle of deterrence of crime, which led to the application of mutilation and death as qualified forms of punishment. Instead of corporal punishment (usually the death penalty), they recommended imprisonment, which would allow for the realisation of a newly defined aim of criminal repression: to pursue the convicted criminal's re-socialisation, to exact a punishment proportionate to the crime, and the utilitarianism of punishment (i.e. using criminals for labour). ${ }^{4}$ As is well known, the

${ }^{2}$ Much has been written about the ideas of philosophers of the Age of Enlightenment and their manifestation in the Polish-Lithuanian Commonwealth. See some of the following studies: M. Affek, Zwiazki polsko-wtoskie w naukach prawnych (1764-1795). Z dziejów humanitaryzacji prawa karnego w Polsce (Warszawa, 1995); A. Lityński, 'O nowej filozofii prawa karnego w Rzeczypospolitej czasów stanisławowskich uwag kilka', Dyplomacja, polityka, prawo. Ksiega pamiątkowa ofiarowana profesorowi Henrykowi Kocójowi w siedemdziesiąta rocznicę urodzin, red. I. Panic (Katowice, 2001), pp. 243-252; T. Adamczyk, 'Problem kary w polskiej myśli humanitarnej XVIII wieku. Uwagi krytyczne', in: $Z$ dziejów prawa, t. 5 (2004), pp. 46-55; idem., 'Kara pozbawienia wolności w myśli humanitarystów polskich', in: $Z$ dziejów prawa, t. 7 (2005), pp. 80-97.

${ }^{3}$ For more details, see: R. Šmigelskytè-Stukienè, 'The Modernisation of the Court System in the Grand Duchy of Lithuania: Changes to the Organisation of the Local District Courts and Regulation of Judges' Duties in 1764-1793', in: Lithuanian Historical Studies, Vol. 21 (2017), pp. 1-3o.

${ }^{4}$ A. Lityński, 'Między realizmem a utopią. Rzecz o humanitarystach oświecenia', Studia z historii państwa, prawa i idei, prace dedykowane profesorowi Janowi Malar- 
greatest attempts at implementing the ideas of the humanist school occurred at the Four Year Diet (1788-1792), as part of the drafting of the criminal law code. ${ }^{5}$ However, separate attempts can be seen in the 1770s: the Polish translation of the programmatic work by Cesare Beccaria On Crimes and Punishments was published in the Polish-Lithuanian Commonwealth in $1772 ;^{6}$ in $1773-1775$ attempts were made at the diet to limit the application of the death penalty; ${ }^{7}$ and in 1776 , the use of torture and the death sentence was banned in cases of witchcraft. ${ }^{8}$ At that time, the Third Statute of Lithuania (TSL), approved in 1588 and considered an almost perfect legal code, was still valid in the Grand Duchy of Lithuania, but by the second half of the 18th century it was being criticised more and more because of its strict forms of punishment: there were around 100 instances where the death sentence applied. Based on an analysis of certain cases heard in the courts of the Grand Duchy of Lithuania at the time, it can be seen in historiography that new ideas would be introduced in court practice much sooner than in legislation. ${ }^{9}$ Nonetheless, there is little research on court practices

czykowi, ed. A. Korobowicz, H. Olszewski (Lublin, 1997), pp. 231-25o; idem., 'Myśl humanitarna w Polsce czasów Oświecenia. Prawo karne materialne', Między humanitaryzmem a totalitaryzmem. Studia z dziejów prawa karnego (Tychy, 2002), p. 43.

${ }^{5}$ Z. Zdrójkowski, 'Nieznane litewskie prospekty karne Józefa Weyssenhoffa z 1792 r. (Nowoodnalezione materiały do dziejów kodyfikacji Stanisława Augusta)', in: Czasopismo Prawno-Historyczne, t. 10, z.1(1958), pp. 91-123; A. Lityński, 'Ustawy karne Sejmu czteroletniego', Rozważania o państwie i prawie, ed. A. Lityński (Katowice, 1993), pp. 116-124; W. Szafrański, Kodeks Stanistawa Augusta (Poznań, 2007).

${ }^{6}$ S. Salmonowicz, 'Lektura Dei delitti e delle pene Cezarego Beccarii (1738-1794) w dwusetlecie zgonu autora dzieła', Z wieku Oświecenia. Studia z dziejów prawa i polityki XVIII wieku (Toruń, 2001), pp. 32-48.

${ }^{7} \mathrm{~J}$. Michalski, 'Problem ius agratiandi i kary śmierci w Polsce w latach siedemdziesiątych XVIII w.', in: Czasopismo Prawno-Historyczne, t. 10, z. 1 (1958), pp. 175-196; A. Lityński, 'Problem kary śmierci w Polsce 1764-1794. Z badań nad historią polskiej myśli prawniczej', in: Czasopismo Prawno-Historyczne, t. 4O, z. 2 (1988), pp. 261-275.

${ }^{8}$ V. Raudeliūnas, 'Tortūros Lietuvos teismuose', in: Socialistinè teisé, No 1 (1977), pp. 44-5o.

${ }^{9}$ M. Affek, Zwiazki polsko-wtoskie w naukach prawnych (1764-1795). Z dziejów humanitaryzacji prawa karnego w Polsce, pp. 128-129. Research into the Krakow Castle Court's practices revealed that the last death penalty to be handed down there was in 1785 , while the last case of capital punishment by quartering was in 1763 , with imprisonment being applied much more widely in the 1770s. T. Adamczyk, 'System kar w prawie ziemskim na przykładzie orzecznictwa sądu grodu krakowskiego w 
from this time in the Grand Duchy of Lithuania. So far, only a few of the activities of the Appeals Court and the Supreme Tribunal of Lithuania have been analysed, which shows that innovative trends associated with the humanist world-view only became apparent in the last decade of the 18th century (1790-1792), whereby other forms of punishment started to be applied more often than the death penalty (usually life imprisonment, and sometimes mandatory service in the army), even though they still had to be confirmed in law..$^{10}$ Research devoted to criminality in the Early Modern Period in Western Europe has revealed that as early as the 16th century, there was a gradual standardisation of how the death penalty was conducted, which eventually led to the rejection of the brutal forms of this punishment, and by the 18th century, the death penalty was applied only in rare cases, even in instances of the most serious crimes. ${ }^{11}$ Milder forms of punishment in criminal law (which began even before the ideas of the legal humanist movement started to spread) can be seen in Poland in the 18 th century; ${ }^{12}$ although, on the other hand, outdated sanctions such as the death penalty and tower punishment still dominated in the laws passed by the diet. ${ }^{13}$

The concept of crime and punishment in the laws of the Grand Duchy of Lithuania has been studied by numerous historians; ${ }^{14}$

XVIII wieku', Culpa et poena: $z$ dziejów prawa karnego, red. M. Mikuła (Kraków, 20o9), pp. 171-182.

${ }^{10} \mathrm{~A}$. Stankevič, 'Nužudymų bylos Lietuvos Didžiosios Kunigaikštystės Vyriausiojo Tribunolo teismo praktikoje (XVIII a. antroje pusejje)', Lietuvos Statutas ir Lietuvos Didžiosios Kunigaikštystės bajoriškoji visuomenè. Straipsnių rinkinys, ed. I. Valikonytė, L. Steponavičienė (Vilnius, 2015), pp. 185-203.

${ }^{11}$ G. Schwerhoff, 'Gewaltkriminalität im Wandel (14.-18. Jahrhundert): Ergebnisse und Perspektiven der Forschung', in: Schweizerische Gesellschaft für Wirtschafts- und Sozialgeschichte, bd. 21 (2006), p. $5^{8 .}$

${ }^{12}$ M. Mikołajczyk, 'Prawo karne materialne w ustawach sejmowych w Polsce w XVIII wieku', Parlamentaryzm i prawodawstwo przez wieki. Prace dedykowane Prof. Stanistawowi Ptazie w siedemdziesiąta rocznicę urodzin, ed. J. Malec, W. Uruszczak (Kraków, 1999), pp. 198-199.

${ }^{13} \mathrm{~T}$. Adamczyk, 'Problem kary i jej rodzaje w ustawach sejmowych w Polsce XVIII wieku', in: $Z$ dziejów prawa, No 6 (2005), p. 75.

${ }^{14}$ J. Malinovskii, Ucheniie o prestuplenii po Litovskomu Statutu (Kiev, 1894); G. Demchenko, Nakazaniie po Litovskomu Statutu v iego triekh redaktsiiakh (1529, 1566 i 1588 gg.) (Kiev, 1894); A. Mikalauskas, Das Strafrecht der drei litauischen Statute von 1529, 1566, 1588 (Kaunas, 1937); S. Vansevičius, Lietuvos Didžiosios Kunigaikštystès 
however, the issue of the application of punishments in the courts and their execution remains unexplored (a little more attention in historiography has been paid to the death penalty only). ${ }^{15}$ The goal of this article is to study the application of forms of punishments of murderers convicted in the noble courts of the Grand Duchy of Lithuania, which heard murder cases as courts of first instance in the second half of the 18th century, or more specifically between 1750 and 1792 (the first interval is relative, while the second marks the date of reforms of the noble courts in the Grand Duchy of Lithuania). Murder cases were chosen as the object of research, as the laws of the Grand Duchy of Lithuania almost always stipulated the death sentence in cases of wilful murder, which philosophers of the Age of the Enlightenment unilaterally opposed. The research mostly refers to verdicts handed down by district castle courts. However, verdicts from other courts are also used: district land courts, the dietine courts that functioned in the interregnum (1764), and the Lithuanian Supreme Tribunal (only on occasions where a murder case was heard here as a court of first instance); 184 verdicts in total where murderers were given a public punishment. The article does not look at punishments handed down to accomplices of murder, or other individuals convicted in murder cases; nor are the issues of the execution of a punishment or adjudicated head money analysed. For the purposes of this

valstybiniai-teisiniai institutai pagal 1529, 1566 ir 1588 Lietuvos Statutus (Vilnius, 1981); A.B. Zakrzewski, 'Ochrona zdrowia i życia w prawie Wielkiego Księstwa Litewskiego w XVI-XVIII wieku', Życie i zdrowie cztowieka w tradycji i kulturze polskiej. Materiaty konferencji „Problematyka życia izdrowia w tradycji i kulturze polskiej, Warszawa, 16 października 2003, ed. W. Bołoz i E. Wolnicz-Pawłowska (Warszawa, 2004), pp. 37-52.

${ }^{15}$ V. Raudeliūnas, 'Mirties bausmė senovės Lietuvoje', in: Pozicija, No 2 (1997), pp. 8-9; G. Zujienè, 'The Death Penalty in Magdeburgian Cities of the Grand Duchy of Lithuania in the Late 16th and Early 17th Century', in: Lithuanian Historical Studies, Vol. 19 (2014), pp. 83-110; idem., 'Mirties bausmė Žemaičiu pilies teisme XVI-XVII a. I pusèje', in: Lituanistica, t. 61, No 2 (2015), pp. 115-127; idem., 'Mirties bausmè Lietuvos Didžiosios Kunigaikštystės bajoriškos teisės aktuose (XV-XVI a.', in: Lietuvos istorijos metraštis. 2015/2 (Vilnius, 2016), pp. 5-32; D. Burba, 'Mirties bausmė bajorams, XVIII a. Vilniaus pavieto pilies teismo bylų duomenimis', Miestas, dvaras, kaimas Lietuvos Didžiojoje Kunigaikštystëje ir Lenkijos Karalystëje XVI-XVIII a. Lokalinès istorijos problemos. Moksliniu straipsnių rinkinys, ed. R. Šmigelskytė-Stukienė (Vilnius, 2018), pp. 367-393. 
article, we are mostly interested in the catalogue of punishments applied in such court cases, and the trends in the application of the punishment, taking into account their compliance with legal norms, and searching for manifestations of humanism in the law.

The concept of a crime committed on a person's life was regulated in great detail in the TSL, while later laws were only episodic (of these, the laws from 1726 were more important, ${ }^{16}$ which prohibited entering into bargains with murderers, and allowed both relatives and unrelated people to be the accusers in murder cases). This is why the article first of all analyses forms of punishment that were applied to murderers as outlined in the TSL, and then looks at other punishments that were handed down in the noble courts of the Grand Duchy of Lithuania in murder cases.

\section{Punishments for murder in the Third Statute of Lithuania}

The Third Statute of Lithuania defines murder as the act of taking the life of a person protected by the law, which could have been done in any number of ways (poisoning, by firearms, or by using weapons capable of chopping, cutting, piercing or other). ${ }^{17}$ At the time, murder was not distinguished from bodily harm that led to the victim's death, both cases were considered as murder. ${ }^{18}$ The premeditated act or wilful guilt category was widely described in the TSL: the wilfullness of the act was demonstrated by its

${ }^{16}$ Volumina Legum (henceforth - VL), t. 6 (Petersburg, 186o), pp. 238, 246-247.

${ }^{17}$ This section was written based on a 1744 edition of the TSL: Statut Wielkiego Xięstwa Litewskiego (Wilno, 1744) and the literature given in footnote 14.

${ }^{18}$ Explanations in historiography of Article 53, Chapter XI of the TSL state that death from injuries was only considered as murder in cases where the injured person died within 24 days of sustaining the injuries, and followed certain conditions during that period (they did not go to any feasts, markets or taverns): A. Moniuszko, 'Przestępstwa przeciw życiu i zdrowiu przed płockim sądem ziemskim pod koniec XVI stulecia', Spoteczeństwo staropolskie, t. II (Warszawa, 2009), p. 16. However, court practices reveal another interpretation of this TSL article, where liability for murder did not apply if the injured person visited a tavern, but died more than 24 days after the injuries were sustained; but, if they visited taverns and died earlier than the 24-day limit, then the accused had to be tried as a murderer, cf. Nachyianalny gistarychny archiu Bielarusi (henceforth NGAB), col. 1710, inv. 1, file 70, pp. 6-7v (Vaulkavysk Castle Court verdict dated 5 September 1785). 
enactment out of ill will or hate; ${ }^{19}$ however, circumstances such as insolence (zuchwalstwo), intoxication (opilstwo), or rage (zapamiętatość) were also valid. Taking someone's life through negligence or by accident was considered unwilfull murder. ${ }^{20}$ In such cases, the accused could only receive a monetary form of punishment, rather than public punishment.

Punishment for wilful murder consisted of two elements: a public death and compositional monetary punishment (known as head money), the amount of which depended on the estate the victim belonged to. The TSL defended the lives of both nobles and persons of non-noble origin (commoners) in this regard: Article 1 Chapter XII foresaw the death penalty for a noble who killed a commoner 'out of insolence, drunkenness or no reason, wilfully', but in that case additional conditions were necessary: he had to be arrested at the scene of the crime, and the sworn oaths of seven witnesses to his criminal guilt had to be provided (of whom at least two had to be nobles). The death penalty also applied to murder carried out among people from the 'ordinary estate' (Article 2, Chapter XII, TSL; and also for the murder of a Jew, Article 7, Chapter XII, TSL). In the case of murder during an argument, the law was more on the side of the accuser: if the accusing side managed to prove the guilt of the murderer, the death penalty would apply (Article 10, Chapter XI, TLS). In some cases, an additional punishment of infamy (dishonour) would be handed down along with the death sentence. It would apply to murder or injury resulting in death: enacted in the presence of the ruler using any type of weapon (Article 9, Chapter I, TLS);

${ }^{19}$ Article 23, Chapter XI of the TSL indicated one important point when talking about unintentional murders, which the court had to determine: '... had there been rows and arguing between those people [the murderer and victim] prior to the act'.

${ }^{20}$ In the explanation of Article 23, Chapter XI of the TSL, the legislator identified five situations that defined the concept of taking someone's life (they included both murder and death from injuries sustained): 1) the murder occurred while shooting a wild animal or bird; 2) if while building a house or erecting a wall, the bricklayer carelessly dropped an object, such as a piece of wood or brick, and it fell and killed someone; 3 ) if while chopping wood, the axe head flew off the axe shaft and mortally injured someone; 4) if a felled tree killed someone in falling; 5) if when shooting a bow or musket at a hat or other target the arrow or bullet strayed and mortally injured someone. 
enacted in the ruler's palace or court using a firearm (gun or bow $)^{21}$ (Article 10, Chapter I, TLS); enacted in court, also enacted against an official of the land, castle, chamberlain's or commissars' court (Article 14, Chapter I, and Articles 7, 62 and 63, Chapter IV, TLS); enacted in a noble's home where the murderer was the wife's lover caught in the act of infidelity (Article 30, Chapter IV, TLS); enacted through deception (Article 17, Chapter XI, TLS); or enacted by a person holding a letter of indemnity (gleitas) issued by the ruler, where the latter committed murder not in defence, but without reason either (Article 13, Chapter I, TLS).

In the majority of documented cases, the law did not indicate how the death penalty would be executed. We should presume that it would be an ordinary death penalty, carried out without any additional torture of the convicted criminal. ${ }^{22}$ According to the practices of the noble courts in the Grand Duchy of Lithuania, the punishment would be performed by chopping off the head of the convicted person with a sword. A qualified form of death penalty was foreseen for either certain forms of murder (murder of a spouse, patricide [parricide], murder of one's lord/master, murder committed by stealth or surprise), or for particular ways the murder was committed (murder by knife, dagger or 'other weapon not meant for battle'). The so-called bag punishment was handed down for the murder of a spouse or one's parents: the convicted person would be driven around a market while having their body ripped apart by hot tongs, and then put into a leather bag with a $\mathrm{dog}$, a rooster, a snake and a cat, whereupon the opening would be sewn up and submerged in water. ${ }^{23}$ The punishment of quartering

${ }^{21}$ From 1601 , also for murder using a firearm enacted during various meetings (dietines), A.B. Zakrzewski, 'Ochrona zdrowia i życia w prawie Wielkiego Księstwa Litewskiego w XVI-XVIII wieku', p. 40.

${ }^{22}$ This punishment was applied for murder during a robbery in a noble's home (Article 18, Chapter II; Article 1, Chapter XI, TSL) to a noble for the murder of a commoner (Article 1, Chapter XII, TSL), for the death of a pregnant woman by pushing her, knocking her down with a horse, hitting or injuring her (Article 15, Chapter XI, TSL), for murder in a duel (Article 14, Chapter XI, TSL), foeticide (Article 6o, Chapter XI, TSL), murder during an argument (Article 10, Chapter XI, TSL), or the starvation of a noble in a private prison (Article 28, Chapter XI, TSL).

${ }^{23}$ S. Godek, 'Kara worka w prawie dawnej Rzeczypospolitej', Contra leges et bonos mores. Przestępstwa obyczajowe w starożytnej Grecji i Rzymie, ed. H. Kowalski, M. Kuryłowicz (Lublin, 2005), p. 94. 
would be applied to those convicted of murdering their lord, and for murder using a knife (Article 16, Chapter XI, TLS). According to Article 17, Chapter XI of the TSL, those who committed murder insidiously, in secret or without engaging in an argument ${ }^{24}$ (by gun or a piercing weapon), had to be tortured to death by 'quartering or impalement'. It was mentioned separately that if a person from a lower estate murdered a noble in this way, the murderer would have to be 'driven out of this world accompanied by brutal torture'.

Milder forms of punishment would be handed down in some separate cases: 1) parents who had murdered their offspring would be sentenced to a year and six weeks in an upper tower, and four acts of public penance (Article 7, Chapter XI, TLS; this legal norm did not encompass acts of abortion by unmarried women or infanticide: these crimes would incur the death penalty);2) murderers of illegitimates/bastards only had to pay head money (always as per a commoner), and only if the victim's mother was alive (Article 32, Chapter XIV, TLS); 3) as for murderers of illegitimates/bastards, only head money would have to be paid for causing death by torture by a torturer, or the starvation of a thief in a private prison who was caught at the scene of the crime. A somewhat more serious form of punishment, one year and six weeks in a lower tower, would be handed down to a murderer if he was acknowledged as psychologically unsound.

Accidental murder would only incur the obligation to pay head money to the victim's relatives, and the amount would depend on the estate the victim belonged to. Murder in cases of necessary defence would not incur any accountability, while permission to murder without penalty a criminal caught at the scene (someone attacking a noble's estate, a thief, or the abductor of a wife) remained as a relic of a blood feud (Article 21, Chapter XIV, and Articles 29 and 30, Chapter XIV, TLS). The law also recognised the institution of 'the beginning' (poczatku): Article 62, Chapter IV of

${ }^{24}$ Article 17 , Chapter XI of the TSL listed the following situations: '[secret murder by] ... launching an ambush on the road, hidden behind bushes, a gate, or in a city, on a village street, or at home from behind a door or window, or in a secret chamber by firearm, or a hand-held weapon, or while the victim was sleeping, or at a feast or other kind of gathering, but by clandestine means with a knife or any other weapon' 
the TSL described physical resistance in response to a verbal or physical attack; if someone launched into an argument in court during which he happened to be killed, the perpetrator 'would not need to be punished'. Whereas someone who killed 'a traitor fleeing to enemy lands' would not only avoid punishment, but would be 'worthy of our ruler's graces' (Article 7, Chapter I, TSL).

\section{The death penalty}

The research shows that in cases when the courts found the accused guilty of wilful murder, the murderer would usually receive the death penalty. ${ }^{25}$ After analysing 184 verdicts handed down by executive noble judicial institutions in the Grand Duchy of Lithuania from 1750 to 1792 , it was found that the death penalty had been handed down in 115 cases to 170 people (thus, it was applied in 62.5 per cent of all murder cases). The reasoning for this verdict in the absolute majority of cases was that 'a crime cannot go without punishment' (administration of justice) and the punishment 'had to deter others from doing similar acts' (general prevention). So, the aims of punishment entrenched in the TSL continued to prevail, while the approach towards punishment of philosophers of the Age of Enlightenment was not reflected at all. ${ }^{26}$ The death penalty was usually applied to people convicted of committing murder during a robbery, to as many as 34 people (the violent theft of another individual's property usually happened while travelling; however, there were also occasions where a noble's home was broken into, or a person was strangled in their sleep). A total of 22 people were convicted of murder during an argument (impulsive crimes arising spontaneously are attributed to this group, where there had not been any conflict between the murderer and the victim in the past: violent altercations between

\footnotetext{
${ }^{25}$ Sometimes it would be applied when the injured victim died after more than 24 days had passed, e.g. the Lida Castle Court handed down the death penalty to a noble in 1778 who had injured his neighbour, who died eight or nine weeks later, NGAB, col. 1722, inv. 1, file 147, pp. 15v-17v (verdict dated 17 December 1778).

${ }^{26}$ For more, see: P. Wiązek, 'Poglądy na cele kary w Rzeczypospolitej czasów stanisławowskich', in: Acta Universitatis Wratislaviensis. Prawo, nr. CCCXV/2 (2013), pp. 33-5o.
} 
drunken individuals who had often spent time in a tavern before the outburst that ended in someone's death prevailed), and for murder during an argument between neighbours (this category was dominated by conflicts over property, usually land and its boundaries: it covered arguments between nobles, and between peasants who were usually defending their right to use land, usually pasture). Another large group of convicted people (20) were those who had murdered their lords (this includes cases where a servant or peasant murdered their lord, land steward or bailiff). ${ }^{27}$ At least 19 people were convicted of a crime identified as murder by a Jew, where the motive was hatred of the Christian religion (these cases cover two instances where Jews had murdered neophytes, and five cases where they were alleged to have conducted ritual murders). Sixteen people were convicted of murder carried out within a family (these cases included the murder of a spouse [sometimes with the help of a lover], the murder of a relative [both blood relative and otherwise], and the murder of a child). There were 15 people convicted of murder out of hatred (this includes cases where the motive for the crime was personal hatred of the victim, evidence of which would have been previous arguments and harm done). Three commoners were convicted for a number of crimes at the same time: rape and murder. The last group of 18 people who received the death penalty involved mostly murders committed while concealing another crime, or cases where the actual motive for the crime could not be determined, and other situations were one-off events (e.g. the abuse of a woman that ended in her death, which began out of fear that she might cast a spell on the perpetrator's home; murder carried out by a quick-tempered noble who would resort to sadistic behaviour when drunk; the beating of a noble suspected of stealing carried out by three peasants that ended in his death; murder carried out on the orders of one's lord).

${ }^{27}$ We should note that in most such cases, criminals who perpetrated murder also robbed their victims, but as sources testify, the preliminary motivation for the crime was not material gain. 


\begin{tabular}{|c|c|c|c|c|c|c|c|c|}
\hline \multirow{2}{*}{$\begin{array}{l}\text { Case cate- } \\
\text { gorisation } \\
\text { according to } \\
\text { the murder } \\
\text { motive }\end{array}$} & \multicolumn{2}{|c|}{ Beheading } & \multicolumn{2}{|c|}{$\begin{array}{l}\text { Beheading and } \\
\text { quartering }\end{array}$} & \multicolumn{2}{|c|}{$\begin{array}{l}\text { Quartering } \\
\text { while still alive }\end{array}$} & \multirow{2}{*}{$\begin{array}{l}\text { Death } \\
\text { by fire- } \\
\text { arms } \\
\text { Noble }\end{array}$} & \multirow{2}{*}{$\begin{array}{l}\text { Total } \\
\text { number } \\
\text { of indi- } \\
\text { viduals }\end{array}$} \\
\hline & Noble & $\begin{array}{l}\text { Com- } \\
\text { moner }\end{array}$ & Noble & $\begin{array}{l}\text { Com- } \\
\text { moner }\end{array}$ & Noble & $\begin{array}{l}\text { Com- } \\
\text { moner }\end{array}$ & & \\
\hline $\begin{array}{l}\text { Murder during } \\
\text { a robbery }\end{array}$ & 6 & 12 & 1 & 10 & & 6 & & 35 \\
\hline $\begin{array}{l}\text { Murder during } \\
\text { an argument }\end{array}$ & 8 & 11 & 1 & 1 & & & 1 & 22 \\
\hline $\begin{array}{l}\text { Murder of } \\
\text { one's neigh- } \\
\text { bour }\end{array}$ & 15 & 5 & 1 & & & & 1 & 22 \\
\hline $\begin{array}{l}\text { Murder of } \\
\text { one's lord }\end{array}$ & 3 & 9 & 1 & 5 & 1 & & 1 & 20 \\
\hline $\begin{array}{l}\text { Murder due } \\
\text { to hatred of } \\
\text { the Christian } \\
\text { religion }\end{array}$ & & 5 & & 4 & & 10 & & 19 \\
\hline $\begin{array}{l}\text { Murder within } \\
\text { the family }\end{array}$ & 7 & 7 & & 1 & & & 1 & 16 \\
\hline $\begin{array}{l}\text { Murder out of } \\
\text { hatred }\end{array}$ & 4 & 8 & & & 1 & 2 & & 15 \\
\hline $\begin{array}{l}\text { Sex-related } \\
\text { motive }\end{array}$ & & 2 & & 1 & & & & 3 \\
\hline Other & 4 & 8 & 1 & 2 & & & 3 & 18 \\
\hline $\begin{array}{l}\text { Total convic- } \\
\text { ted of murder }\end{array}$ & 47 & 67 & 5 & 24 & 2 & 18 & 7 & 170 \\
\hline
\end{tabular}

Thus, on one hand, the noble courts tried to abide strictly by the norms set down in the TSL, and to hand down the death penalty to murderers; ${ }^{28}$ and on the other hand, we can see that attempts were made to find a milder way of carrying out the death penalty: in 88

${ }^{28}$ In cases where a noble murdered a person from a lower estate, the death penalty was only applied a few times. For example, on 2 March 1767, the Mozyr Castle Court applied the penalty to Jan Maciej Bujanowski. The latter held the position of supervisor of the Horbowicze estate, and while he was drunk, he shot one of his subjects, the furrier Józef Sołujan. He tried to flee from the estate, but was seized by local peasants, and his guilt was proven in court by a former employer. Five peasants and two nobles agreed to swear an oath substantiating Bujanowski's guilt. Thus, all the conditions mentioned in Article 1, Chapter XII of the TSL were implemented (NGAB, col. 1728, inv. 1, file 35, pp. 10-12v.). In other cases, these conditions were rarely carried out, so nobles often avoided the death penalty. 
per cent of all cases, convicted murderers were to receive the usual death penalty of beheading or death by firearms: i.e. during the execution, the convicted individual was not to experience any additional torture. Orders were given to quarter some beheaded people after their death (the law foresaw only the quartering of a living person), while the quartering of a living person was handed down to almost 12 per cent of convicted murderers (but hardly ever to noblemen).

A regular death penalty was handed down for the murder of a neighbour (also in cases where a murder occurred by means of ambush or similar stealth), and for murder arising from an argument. ${ }^{29}$ In the practice of the noble courts, the qualified death penalty outlined in the law for murdering one's lord ${ }^{30}$ or a murder in the family ${ }^{31}$ (patricide, or the murder of a spouse) was practically never applied; instead, an ordinary beheading would be applied.$^{22}$ In actual fact, quartering was applied only to certain crimes: for people convicted of ritual murder (ten Jews within the boundaries of this research), three people convicted of murder committed out of hatred (in all cases, these were Jews), and in some cases of robbery (usually when commoners not only murdered a noble during a robbery, but also when it happened while breaking into their homes; 33 the most terrible form of death

\footnotetext{
${ }^{29}$ The only instance where prior to a beheading, the murderer's hand was also to be burned was a case where the nobleman Szymon Korzun was put on trial for the murder of the Tołoczyn clergyman Fr Rajmund Tomkowicz, NGAB, col. 1731, inv. 1, file 82, pp. 85-88 (Orsha Castle Court verdict dated 6 July 1758).

${ }^{3 \circ}$ The only quartering in these cases related to the crimes of a noble who not only killed his own lord, but was also the lover of the lord's wife, NGAB, col. 1705, inv. 1, file 206, pp. 12v-14v (Brest Castle Court verdict dated 23 December 1771).

${ }^{31}$ The penalty given to a woman, her husband and their maid for murdering the woman's father was not the routine bag penalty outlined in the law but beheading, NGAB, col. 1705, inv. 1, file 203, pp. 109-111 (Brest Castle Court verdict dated 18 November 1755).

${ }^{32}$ This occurred even in cases when peasants murdered a noble. But in these cases there were sometimes instructions to symbolically chop off their hands after being executed, as a punishment 'for raising their hand against the nobility'. See: Lithuanian State Historical Archives (henceforth - LVIA) col. SA, file 14013, pp. 26v-27v (Vilkmergè Castle Court verdict dated 26 March 1768); NGAB, col. 1727, inv. 1, file 101, pp. 118-128v (Minsk Castle Court verdict dated 3 March 1770).

${ }^{33}$ On 7 May 1768, the Vaulkavysk Castle Court handed down the penalty of quartering to Antoni Ciereszko, who, having been hired by the noblewoman Małgorzata $\mathrm{z}$
} 
penalty applied to this category of crime).. ${ }^{34}$ Most qualified death penalty verdicts were announced in the 175 os and 176 os, with the last one in 1786 when the Breslau Castle Court handed down the verdict to a participant in a robbery during which three people were murdered. ${ }^{35}$

The death penalty by firearms did not really exist in the noble law of the Grand Duchy of Lithuania, and it was only applied episodically to noblemen (seven people, including one juvenile who shot his lord) under various circumstances (an officer, a wife murderer, or when the murder instrument was a gun). But the essential factor here was probably the fact that there were no executioners in certain cities who could conduct these punishments: Vilkmergė, Telšiai, Minsk or Mstislavl (orders were given to have these executions conducted by the court elder's garrison, or a unit of the army of the Grand Duchy of Lithuania that was staying in the city).

Without going into detail about whether death penalties were carried out, it is important to note that in certain cases, when the litigants did not swear the oath given to them, the court would order the release of the murderer, ${ }^{36}$ or at the litigants' request, the sentence would be milder (an ordinary instead of a qualified death

Lindzów Jaskołdowa to make woollen overcoats, ended up hacking her, her children aged six and 13, and a hired hand to death with an axe in the night (the file mentions that he had also murdered a peasant beforehand), NGAB, col. 1710, inv. 1, file 67, pp. 117v-119; on 7 March 1778, the Brest Castle Court handed down this penalty to two peasants who had strangled a nobleman in his own home, ibid. col. 1705, inv. 1, file 207, pp. 22-28; LVIA, col. SA, file 14022, pp. 4v-6 (Vilkmergè Castle Court ruling dated 31 March 1787 on a case where a peasant had murdered a nobleman and his son in their own home).

${ }^{34}$ According to the Brest Castle Court verdict of 7 March 1778, two peasants, Matwiej Semeńczuk and Maxym Jakowczuk, were found guilty of the death of the nobleman Mikołaj Kościuszko. Enticed by his money and property, first they tried to poison the nobleman, and later, entering his home at night, they strangled and brutally murdered him 'in a way unlikely to have ever been done before'. The court ordered both murderers to have their arms chopped off at the elbow as part of their execution, then to be quartered alive, and to have their quartered body parts mounted on poles, NGAB, col. 1705, inv. 1, file 207, pp. 22-28.

${ }^{35}$ For more details, see: A. Stankevič, 'Nužudymų bylos Lietuvos Didžiosios Kunigaikštystės Vyriausiojo Tribunolo teismo praktikoje (XVIII a. antroje pusẻje)', p. 191.

${ }^{36}$ At least six people avoided the death penalty in this way. 
penalty), ${ }^{37}$ or the death penalty would be disregarded altogether, and the case would be confirmed as ending with an agreement reached between the litigants, ${ }^{38}$ even though these possibilities were not outlined in the law.

\section{Tower penalties}

As was mentioned earlier, in certain cases, the laws of the Grand Duchy of Lithuania stipulated a penalty for murder of one year and six weeks in a lower tower (if the convict was acknowledged as being psychologically unsound), or a period of the same duration in an upper tower (for parents who had murdered a child). In Poland at the time, the main public punishment for murder was imprisonment in a lower tower for a year and six weeks, while the death penalty was handed down only in exceptional cases. ${ }^{39}$ The 'tower penalty' was the main form of imprisonment applied to nobles (they were also considered exclusively noble by the fact that the convict would have to arrive of his own accord at a set time at the place of imprisonment). In the Polish-Lithuanian Commonwealth, the main sites that performed the function of

${ }^{37}$ On 15 March 1766, the Vaulkavysk Castle Court applied the death penalty by quartering to the nobleman Michał Lewoniewski, who had imprisoned privately another nobleman, Michał Orda, in 1759, torturing him in all sorts of ways for four days until he died (this was probably a way of getting rid of a member of an opposing political faction), NGAB, col. 1710, inv. 1, file 65, pp. 100-102v. Later, the court agreed to satisfy the accuser's request to change the qualified death penalty to an ordinary one.

${ }^{38}$ In the Minsk Castle Court verdict of 7 September 1781, two subjects of the Wielatycz elder Józef Tyszkiewicz were accused of murdering the nobleman Jerzy Bujalski. The accused tried to prove that Bujalski was murdered as an assailant, but the court handed down an oath to the accusers, who were ordered to swear that Bujalski had been killed furtively. The convicted Amelian Kopyciewicz and Łauren Młynarz were given the death penalty, but on the day of their execution (possibly after some negotiations), Tyszkiewicz renounced his right to the peasants, while the accusers (the Bujalski family) granted the convicted their lives, but took on the right to keep them as 'eternal slaves and prisoners', NGAB, col. 1727, inv. 1, file 102, pp. 100-106v. The formula chosen was anachronistic, as the TSL was already talking about the abolition of the institution of holding captives.

${ }^{39}$ A. Moniuszko, 'Przestępstwa przeciw życiu i zdrowiu przed płockim sądem ziemskim pod koniec XVI stulecia', p. 27; M. Kamler, Przemoc między szlachta sieradzka w XVII wieku. Opis zjawiska (Warszawa, 2011), pp. 168-171. 
imprisonment were castle and wall towers. ${ }^{40}$ The tower would be divided into two parts: a lower section, usually dug into the ground, known as a lower tower, and above it an upper tower. The lower section was a cellar, an underground space, ${ }^{41}$ where there were no conveniences, windows, doors or chimneys. The convict would be lowered down by ropes through a hatch in the floor. The upper part of the tower offered much better conditions: a simple room with windows and chimneys, and a fireplace.

During the period analysed in this research, the noble courts of the Grand Duchy of Lithuania handed down a lower tower penalty to murderers in a total of 42 cases (in all instances, to noblemen). In 28 cases (affecting 41 people), the prison term was a year and six weeks, in ten cases (affecting 11 people) half a year, and in four cases (affecting five people) 12 weeks.

Out of the people who were given the maximum penalty of a year and six weeks in a lower tower, only one was found to be psychologically unstable. ${ }^{42}$ In the other cases, three reasons can be distinguished for applying this punishment. The first was only in cases: 1) when a murder happened after a spontaneous argument, a row over land borders, or during armed altercations between political factions; 2) when the murderer was a noble, and the victim was a commoner. The second reason was that the punishment was applied when the court had insufficient evidence for handing down the death penalty (i.e. it was unclear who had started the argument, or what circumstances led to the death, whether it was an injury inflicted by someone else, or self-inflicted), or when there were uncertainties regarding the type of liability that should be applied..$^{43}$ The third reason for applying the tower penalty is

${ }^{40}$ W. Maisel, Archeologia prawna Polski (Warszawa-Poznań, 1982), p. 141.

${ }^{41}$ The law of 1726 demanded that the cellar be 12 ells (over seven metres) deep, $V L$, Vol. 6, p. 247.

${ }^{42}$ NGAB, col. 1722, inv. 1, file 153, pp. 29-30 (the Lida Castle Court verdict of 29 October 179 o deemed the nobleman Antoni Zaleski, who had killed his wife, to be suffering from a psychological illness; judging by the facts given in the file, the man was probably schizophrenic).

${ }^{43}$ For example, in 1777 the Šiauliai Castle Court applied the one year and six-week lower castle penalty to six noblemen from the Telšiai district who had formed a independent court in 1769, where they put their neighbour, the noblewoman Maryanna $\mathrm{z}$ 
particularly interesting, as it reflects the aim of applying a public punishment to the most serious crimes even in cases where the law did not foresee it: having found that a murder was accidental, the argument was provoked by the murdered individual, or when the victim died 24 days after being injured. ${ }^{44}$ In these cases, the court would either not base its decision to apply the punishment on any law, or it would refer to a Polish law from 1550 which stated that 'a murderer must be imprisoned in a lower tower for one year and six weeks. ${ }^{45}$ In one case, the court even referred to another Polish law from 1496, which stipulated the tower penalty in murder cases. ${ }^{46}$

Sixteen people were given a shorter lower tower penalty term (half a year or 12 weeks), but the instances where this applied were similar to those mentioned above: unintentional murder, murder arising from an argument or rows over land boundaries, in a duel, or in self-defence.

Upper tower imprisonment was handed down to murderers only on exceptional occasions: only to four people in four cases. The longest term foreseen by the law (one year and six weeks) was given in 1766 according to the TSL: to a noblewoman for murdering her child. ${ }^{47}$ In two other cases, terms of six weeks were given to

Dobszewiczow Kibortowa, on trial for witchcraft, and carried out the death penalty themselves, by burning her on a pyre (only state courts could rule on such cases), LVIA, col. SA, file 14856, pp. 87-94.

${ }^{44}$ For example, in 1786 and 179 o, the Raseiniai Castle Court applied this penalty twice, reasoning that the injured person did not die immediately, but after a period of time had passed (in the first case, after six weeks, and in the second after four months), LVIA, col. SA, file 19500, pp. 179v-182; file 19506, pp. 114-122.

${ }^{45}$ LVIA, col. SA, file 18571 , pp. $175^{-178 v}$ (Vilkmergè Castle Court verdict dated 12 December 1766); file 5977, pp. 220-223v (Trakai Castle Court verdict dated 28 March 1767); file 5997, pp. 12-24 (Trakai Castle Court verdict dated 14 May); NGAB, col. 1705, inv. 1, file 205, pp. 66-70 (Brest Castle Court verdict dated 14 May 1766); col. 1733, inv. 1, file 89, pp. 119v-128 (Pinsk Castle Court verdict dated 22 May 1785).

${ }^{46}$ NGAB, col. 1722, inv. 1, file 151, pp. $36-39 v$ (Lida Castle Court verdict dated 8 May 1788). A. Moniuszko, 'Przestępstwa przeciw życiu i zdrowiu przed płockim sądem ziemskim pod koniec XVI stulecia', p. 14. In such cases, the judgement passed was not based on law digests but on editions of the TSL where these laws were listed, as is shown by the respective references made to them.

${ }^{47}$ This punishment was applied to the noblewoman Maryanna z Połubińskich Bykowska, previously Komajewska, who, punishing her daughter from her first marriage 
nobles; and in one other case, a burgher received a punishment for murdering a nobleman in self-defence, 'instead of the upper tower', 12 weeks in the town hall prison. In these cases, the crime was found to be unintentional murder.

\section{Corporal punishment (beatings)}

The laws of the Grand Duchy of Lithuania did not foresee any instance where corporal punishment could be handed down to convicted murderers. The research shows that in the second half of the 18th century in Poland, beatings were considered a universal form of punishment given to commoners for almost any crime they had committed. ${ }^{48}$ Beatings were widely applied to commoners in the Grand Duchy of Lithuania as well, and sometimes also in murder cases. In total, this form of punishment was handed down in 14 cases to 15 people (in another two cases, three people received beatings as an additional punishment), but in actual fact, it was only meant to be applied in certain cases: when the court had insufficient evidence to order the death penalty (when the circumstances in cases were not clear, or when there was no one to swear an oath of incrimination), ${ }^{49}$ unintentional murder (usually in cases where the murder was the result of inappropriate

for an unexplained 'childish habit', kept her tied with a rope around the neck to the shutters until she suffocated. The court ordered the remaining five children (three boys and two girls) from her first marriage to be removed from the home, with the boys being sent away to schools, and the girls to convents (the girls were banned from visiting their mother until they came of age), NGAB, col. 1710, inv. 1, file 67, pp. 15-20v (Vaulkavysk Castle Court verdict dated 18 August 1766).

${ }^{48}$ M. Mikołajczyk, Przestępstwo i kara w prawie miast Polski południowej XVI-XVIII wieku (Katowice, 1998), p. 217. See also: T. Adamczyk, 'Kary cielesne w Polsce XVIII wieku', Między I a III Rzeczapospolita. Ksztattowanie europejskiej kultury prawnej. Prace ofiarowane prof. zw. dr. hab. Adamowi Lityńkiemu w czterdziestolecie pracy naukowej, ed. M. Mikołajczyk, A. Drogoń (Tychy Śląsk, 2005), pp. 23-41.

${ }^{49}$ For example, on 24 March 1768 , the Vilkmerge Castle Court stated that the death penalty should apply to the peasant woman Magdalena Szwabówna for the murder of her new-born baby; however, since there was nobody who would agree to swear to an accusation against her, she was given corporal punishment (30o beatings with a rod over the course of three weeks, 100 whips on every market day) and forced to do penance (for this punishment, she was sent to the Maišiagala priest), LVIA, col. SA, file 14013, pp. 19v-2O. 
behaviour by the accused, termed 'insolent'), ${ }^{50}$ or overstepping the limits of necessary defence. Meanwhile, in cases of intentional murder, beatings were only handed down in place of the death penalty when the convicted had not yet come of age. Both these cases are associated with the Rechytsa Castle Court's verdicts: a 17 -year-old peasant who had killed his wife in 1790 was to receive two rounds of beatings, 600 times with a rod each time, ${ }^{51}$ while in 1791 a 16-year-old peasant was to receive beatings over a six-month period for murdering a young shepherd, receiving 133 blows with a rod every Friday..$^{2}$ In other cases, the number of blows varied from 5 o to 1,000 , usually in quantities of 5 o, 100, 15 o, 300 or 5 oo. In almost all cases, beatings were to be carried out with a rod, and only in one case with a stick. This form of punishment was to be conducted in public, usually with the convict undressed in the city market and tied to a pole of shame.

\section{Other punishments}

The courts rarely applied other forms of punishment not outlined in the law: only in nine cases affecting 18 people. Imprisonment dominated in this category. This punishment did not exist in the laws of the Grand Duchy of Lithuania, so neither were there

${ }^{50}$ For example, on 6 May 1785 , the Kaunas Castle Court handed down a punishment of 100 beatings to the Jew Orel Wolfowicz for jokingly playing with the trigger on a pistol, which accidentally fired, and mortally wounded one of the staff, LVIA, col. SA, file 19621, pp. 15ov-152.

${ }^{51} \mathrm{NGAB}$, col. 1736, inv. 1, file 44, pp. 26v-29. In this case, the court stated as follows: Article 8, Chapter VI of the TSL only allowed summoning juveniles to court in six cases, and in Article 1 of the same chapter, the age of adulthood for a man was given as 18. Based on this, the accused could be exempted from the death penalty (in actual fact, the article outlined cases where the court could deliberate on claims to the property inherited by juveniles). Other examples of interpretation would be the Vilkmergè Castle Court ruling of 20 December 1781, whereby an underage noble servant had fatally shot his lord: in response to the accused's request to take his young age into account, the court replied that the law of 1726 did not allow murderers to be let off their punishment, while Article 19, Chapter XI of the TSL said that the death penalty applied to the murder of one's lord/master, with no exceptions being made for age (orders were given for the murderer to be shot dead), LVIA, col. SA, file 14019, pp. 212v-214.

${ }^{52} \mathrm{NGAB}$, col. 1736, inv. 1, file 44, pp. $3^{2-33 v .}$ 
buildings where it could be carried out. Life imprisonment appeared for the first time in the laws of the Polish-Lithuanian Commonwealth only in 1791, when it could be handed down for undetailed crimes against the nation, or high treason. ${ }^{53}$ In Europe at this time, however, imprisonment was widespread. In Poland as well, there were two large prisons in the 18th century, in the fortresses in Częstochowa and Kamianets-Podilskyi (they had permanent army garrisons to repel attacks by the Turks and the Tartars). ${ }^{54}$

In seven cases, a fixed or indeterminate term in prison as a punishment in the practices of the noble courts of the Grand Duchy of Lithuania in the period under analysis was handed down to 14 people. Probably the earliest instance when imprisonment was handed down to murderers in the Grand Duchy of Lithuania was on 18 July 1779, as the verdict of the Pinsk Castle Court, in a case where two peasants were tried for the death of a Pinsk glass cutter, the Jew Josiel Jankielowicz, nicknamed Kozaczek. ${ }^{55}$ The court found that almost three months had passed from the injury to the victim's death, and therefore acquitted the accused of the death penalty which would otherwise apply. It was decided to give the murderers different forms of punishment: Semen Kłyszko, who had been convicted for stealing numerous times, was given the penalty of 'eternal imprisonment', while since this was the first conviction of Jakub Korol (also known as Kalenik), he was given a punishment of three years in prison 'chains'. The punishment had to be accompanied by forced labour; however, since the court stated 'on account of the disorder in the state, there are no fortresses', he was sent away to be imprisoned in the

${ }^{53}$ T. Adamczyk, Problem kary i jej rodzaje $w$ ustawach sejmowych $w$ Polsce XVIII wieku, p. 66.

${ }^{54}$ W. Zarzycki, 'Więziennictwo czasów stanisławowskich', in: Problemy praworządności, No 8-9 (1985), pp. 112-119; J. Bieda, 'Cele i organizacja zakładów karnych w I Rzeczypospolitej', in: Acta Universitatis Lodziensis. Folia Historica, nr. 94 (2015), pp. $81-85$.

${ }^{55}$ Peasants injured a Jew during a robbery which occurred in late November 1778 : his throat was slit with a knife, and ten injuries were made to his head. However, because the perpetrators were drunk, they did not manage to kill him, and the injured man only died on 21 February 1779. 
Pinsk Dominican friary, and was ordered to work in the 'factory' of the friars..$^{6}$

The impulse to apply imprisonment as punishment in the Grand Duchy of Lithuania came about with the Permanent Council's Cardinal Laws of 11 January 1782, which urged it to be used instead of the death penalty. It ordered sending to the prison in Kamianets-Podilskyi convicts who had been sentenced to terms ranging from a year to life in prison (and for shorter periods in closer locations ). ${ }^{57}$ Even though the Cardinal Laws did not carry the power of law, soon enough the courts of the Grand Duchy of Lithuania began to hand down prison terms based on its contents. These were usually applied in cases of the murder of a commoner. It was applied probably only in one instance for the murder of a noble: on 18 December 1783 , the Navahrudak Castle Court found four people guilty of murdering the nobleman Bogusław Moroz (he was hacked to pieces with swords in his own home, when arguments arose between the nobles over property), but basing its verdict on the Permanent Council's Cardinal Laws, it did not apply the death penalty but imprisonment: life imprisonment for two people, 'the most guilty, for spilling blood'; and five years in prison at Kamianets-Podilskyi for the other two, for their role as accomplices..$^{58}$ Imprisonment for the murder of a commoner was handed down in six cases to ten commoners: 'eternal' imprisonment for five people, ${ }^{59}$ ten years in prison for three people (one was also

${ }^{56} \mathrm{In}$ addition, corporal punishment was also prescribed: both the convicted men first of all had to receive three rounds of beatings, with 300 strokes with a rod each time, with subsequent beatings of 100 strokes for Kalenik every quarter in the year until the punishment was completed, and for Kłyszko each month for the rest of his life. In the end, it was prescribed that if the convicted fled from the monasteries, the punishment would be stricter: Kalenik would be sent to prison for life, while Kłyszko would receive the death penalty. On 3 September the same year, Kłyszko did flee from the monastery, but was soon captured, and this time the court ruled that he should be beheaded, NGAB, col. 1733, inv. 1, file 88, pp. 159-161v, 178v.

${ }^{57}$ A. Czaja, Między tronem, butawa a dworem petersburskim. Z dziejów Rady Nieustającej 1786-1789 (Warszawa, 1988), pp. 245-246.

${ }^{58} \mathrm{NGAB}$, col. 1730, inv. 1, file 411, pp. $255 \mathrm{v}-259 \mathrm{v}$.

${ }^{59}$ This punishment was handed down to murderers by the Vaulkavysk Castle Court, which convicted three peasants on 5 September 1785 (Michał Bondar, his son Antoni and his son-in-law Józef Hlebik), for beating up a local peasant Siemion Leszczuk in a tavern (who died two weeks afterwards), NGAB, col. 1710, inv. 1, file 70, 
sentenced to beatings), ${ }^{60}$ six years in prison for one ${ }^{61}$ and three years in prison for another (see the above-mentioned Pinsk Castle Court verdict; in all cases, the punishment had to be carried out at Kamianets-Podilskyi).

The noble courts of the Grand Duchy of Lithuania handed down different forms of punishment to four other commoners. In the middle of 1777 , the Pinsk Castle Court presided over a case where two peasants, Chwedor and Sidor Szłomczukow, were accused of murdering the peasant Hryc Josypow, who lived in the Pinsk estate. He was stealing fish from traps set by the Szłomczukows, who decided to catch the thief, which is what they did. Lying in wait, they caught Josypow in the act of stealing, whereupon they beat him up and left him to die. The court found that their crime deserved the death penalty; however, this was not demanded by either the murdered man's sons or the peasant's lord, who was the Lithuanian Hetman Michał Kazimierz Ogiński. The latter asked that the court hand down corporal punishment, and send them to work with barrows at the fort. The court did as it was asked: each offender received 200 strikes with a rod, and was sent for a year and six weeks to work in Telechany, ${ }^{62}$ to help dig the

pp. $6-7$ v. The court heard that the crime occurred during an argument, but was not intentional (the TSL did not foresee this interpretation). In 179o, the Lida Castle Court applied this punishment to the peasant Mateusz Pieckiel for hitting a peasant on a market day, which ended with the victim's death, ibid. col. 1722, inv. 1, file 153, pp. 26v-28v (Lida Castle Court verdict dated 13 July 179o).

${ }^{60}$ This punishment was handed down on 9 May 1785 by the Kaunas Castle Court to the peasant brothers Maciej and Bartłomiej Poderiai, who lived in the Rumšiškès district, for the murder of the peasant Szymon Dubowski in Vilijampole (the crime occured during an argument in a tavern; the court ordered this punishment due to insufficient evidence for ordering the death penalty), LVIA, col. SA, file 19621, pp. 152155. The same prison term was given on 27 February 1788 by the Brest Castle Court to the soldier Andrzej Kisielewski, who mortally wounded a local peasant during an argument in Bereza (the argument flared up in a tavern for accidentally stepping on a foot), NGAB, col. 1705, inv. 1, file 209, pp. 240-243v.

${ }^{61}$ A six-year prison term was ordered on 23 March 1784 for Andrzej Totyłło, a resident of the village of Tilvikai, who killed his neighbour's wife during a brawl (all the participants in the conflict were drunk). In this case, the Raseiniai Castle Court stated that Totyłło had not intended to commit the crime, but did it 'out of anger', LVIA, col. SA, file 1950o, pp. 53v-59 (in the TSL, 'anger' was a sign of intentional murder).

${ }^{62}$ NGAB, col. 1733, inv. 1, file 88, pp. 116v-118v (28July 1777, Pinsk Castle Court verdict). 
famous Ogiński canal, which had been under construction since 1765, and crossed this particular town (these Pinsk Castle Court verdicts of 1777 and 1779 were the only ones that involved forced labour for murderers; probably in the second case, the punishment was applied with Ogiński's request for labourers in mind). On 20 March 1789, the Navahrudak Castle Court convicted two Muscovites, Prosko Popławka and Cimocha Prokowin, of the murder of Semen Polak, who was travelling with them. The court stated that they deserved a more serious punishment; however, since there was no accuser who could swear on their guilt, it applied an alternative punishment. Popławka was ordered to serve with the troops in Navahrudak for the rest of his life, and Prokowin, who was deemed less guilty, but 'still involved in this activity', had to serve with the troops for 12 years. ${ }^{63}$ It is worth remembering that this verdict was issued six months after a law was passed to increase the size of the Polish-Lithuanian Commonwealth's army to 100,000 soldiers (it proved to be quite difficult).

\section{Concluding remarks}

To conclude, it is worth drawing attention to two points: the state of the law in the Grand Duchy of Lithuania, and the legal culture among the nobility. In the 18th century, civil law as outlined in the TSL still met society's needs quite well; however, norms of criminal law had become significantly outdated, while sometimes people tried to exploit the severity of the punishments outlined in the legal code for propaganda aims. ${ }^{64}$ During the reign of Stanislaw Augustus Poniatowski, significant moves were made to create a new legal code in the Polish-Lithuanian Commonwealth: this was particularly important to Poland, which did not have an innovative code at the time. Nonetheless, the nobility in the Grand Duchy of

${ }^{63}$ NGAB, col. 1730, inv. 1, file 411, p. 114.

${ }^{64}$ After the First Partition of the Polish-Lithuanian Commonwealth, the Russian administration publicly announced the abolition of 'horrid tortures' and 'all manner of strict executions and punishment' in its incorporated territories, see: S. Godek, 'O prawie i sądach w guberniach białoruskich w świetle aktów władz rosyjskich z 1772 roku', in: Zeszyty Prawnicze Uniwersytetu Kardynata Stefana Wyszyńskiego, t. 10, z. 1 (2010), pp. 181-182. 
Lithuania fiercely opposed any attempts to change the TSL. ${ }^{65}$ At the Four Year Diet (1788-1792), the Lithuanian nobility was persuaded to participate in the creation of a legal code that would apply to the whole state, convincing them that it would be based on the TSL. Alas, this was just a trick, since no one was prepared to revert to those outdated norms. ${ }^{66}$ An analysis of court hearings of murder trials also reveals the nobility's strong attachment to its legal code: in many cases, when ordering a form of punishment, they relied on the appropriate TSL norms.

The legal culture among the nobility in the Grand Duchy of Lithuania remains little studied to this day. The most important works on the topic were written by the legal historian Andrzej B. Zakrzewski. ${ }^{67}$ As well as other conclusions, he made the following observations relating to abiding by the law and legal practice: he stated that, on one hand, the nobility officially respected the law, demanding strict adherence to the letter; but on the other hand, when it affected their interests, they looked for all sorts of exceptions. When judging people from other estates, they would be given the strictest possible punishment outlined by the law. When it came to the nobility, however, the law was not followed so strictly, and the trend was to apply milder forms of punishment and use third-mediation to achieve an alternative agreement. As this researcher has noticed, there were examples where strict punishments were applied to the nobility as well. Punishments for murder in the noble courts of the Grand Duchy of Lithuania seem to confirm these conclusions: the courts applied the punishment foreseen by the TSL rather strictly regarding murderers from the lower estates; moreover, they applied these forms of punishment even in cases where the law did not stipulate this (for uninten-

${ }^{65}$ J. Malec, 'Walka szlachty litewskiej o zachowanie III Statutu w drugiej połowie XVIII wieku', in: Czasopismo Prawno-Historyczne, t. 44, z. 1-2 (1992), pp. 65-71.

${ }^{66}$ A.B. Zakrzewski, 'Naiwność czy taktyka? Uzasadnianie prób unifikacji prawa litewskiego i koronnego XVI-XVIII wieku', Lietuvos Statutas ir Lietuvos Didžiosios Kunigaikštystès bajoriškoji visuomené. Straipsniu rinkinys, ed. I. Valikonytė, L. Steponavičienè (Vilnius, 2015), pp. 75-83.

${ }^{67}$ A.B. Zakrzewski, 'O kulturze prawnej Wielkiego Księstwa Litewskiego XVIXVIII wieku - uwagi wstępne', in: Kultura i języki Wielkiego Księstwa Litewskiego, ed. M.T. Lizisowa (Kraków, 2005), pp. 33-63. 
tional murder). In the meantime, the implementation of qualified death penalties hardly applied at all to nobles, who usually avoided the death penalty by replacing it with another punishment, even if it was not outlined by any law. There were instances of strict sentences being handed down to nobles; like the commoners, they would also be punished for unintentional murder. This could be considered as a rather archaic legal consciousness among the nobility, and the meagre influence of Enlightenment ideals on the noble courts in the Grand Duchy of Lithuania.

\section{Conclusions}

The research reveals that between 1750 and 1792 , the noble courts of the Grand Duchy of Lithuania convicted 264 people in 184 cases of murder, of whom 170 (or 64.4 per cent) were given the death penalty, 61 received the tower penalty (23.1 per cent), 15 people (5.7 per cent) received corporal punishment (beatings), while 18 people (6.8 per cent) received other forms of punishment not outlined in the law (imprisonment, forced labour, or obligatory service in the army). This meant that old forms of punishment outlined in the TSL dominated (incidentally, they were not always applied exactly according to this legal code). Alternative forms of punishment were episodic, and applied only to a small number of convicts. Imprisonment, as the punishment recommended by philosophers of the Age of Enlightenment, was applied in only 5.3 per cent of murder cases; their application in most cases was related to the publication of the Permanent Council's Cardinal Laws in 1782 .

In cases of wilful murder, the death penalty as outlined in the law usually applied. Exceptions were made mostly only for those from the noble estate who were convicted, who would sometimes be given the lower or upper tower penalty, instead of the death penalty. Tower penalties normally applied to other crimes, and not murder. The punishment of infamy was never applied in murder cases. When handing down the death penalty, the courts usually avoided qualified forms of implementation, as 'official' forms of punishment, such as the bag, being seated on the pole, or brutal 
torture, were not applied in practice. From the range of qualified forms of punishment, only quartering was sometimes applied, and mostly to those who were convicted of a specific crime, ritual murder and certain cases of robbery.

The research also shows that the courts tried to apply public punishment (the tower penalty to nobles, and beatings to commoners) in cases where the law did not call for it: when there was insufficient evidence, and in cases of unintentional murder or excessive necessary self-defence.

The court verdicts reveal the conservativism of the estate of nobles, and their efforts to continue to adhere to the strict laws in the TSL. It is likely that this practice could have depended on the poor state of the penitentiary system, since there was not a single public prison in the Grand Duchy of Lithuania at the time that could be used for long-term imprisonment. However, it was forced to change quite soon: after the Third Partition of the Polish-Lithuanian Commonwealth in 1795, the territory of the Grand Duchy of Lithuania ended up being incorporated into the Russian Empire, a state where the death penalty had been abolished.

Author Details

Adam Stankevič is a historian with a doctorate in humanities, and a research fellow in the Department of the History of the Grand Duchy of Lithuania at the Lithuanian Institute of History. His academic fields of interest are the activities of the courts in the Grand Duchy of Lithuania in the 16th to the 18th centuries, and the history of crime.

Address: Lithuanian Institute of History, 5 Kražių St, Vilnius LT-o11o8, Lithuania Email: stankevic.adam@gmail.com

\section{Bibliography}

ADAMCZYK, Tomasz. 'Problem kary w polskiej myśli humanitarnej XVIII wieku. Uwagi krytyczne', in: Z Dziejów prawa, t. 5 (2004), pp. 46-55.

ADAMCZYK, Tomasz. 'Kara pozbawienia wolności w myśli humanitarystów polskich', in: $Z$ Dziejów prawa, t. 7 (2005), pp. 80-97.

ADAMCZYK, Tomasz. 'Problem kary i jej rodzaje w ustawach sejmowych w Polsce XVIII wieku', in: Z Dziejów prawa, nr. 6 (2005), pp. 59-76. 
ADAMCZYK, Tomasz. 'Kary cielesne w Polsce XVIII wieku', in: Między I a III Rzeczapospolita. Ksztattowanie europejskiej kultury prawnej. Prace ofiarowane prof. zw. dr. hab. Adamowi Lityńskiemu w czterdziestolecie pracy naukowej, ed. M. Mikołajczyk, A. Drogoń (Tychy Śląsk, 2005), pp. 23-41.

ADAMCZYK, Tomasz. 'System kar w prawie ziemskim na przykładzie orzecznictwa sądu grodu krakowskiego w XVIII wieku', in: Culpa et poena: $z$ dziejów prawa karnego, red. M. Mikuła (Kraków, 20o9), pp. 171-182.

AFFEK, Mariusz. Zwiazki polsko-wtoskie w naukach prawnych (17641795). Z dziejów humanitaryzacji prawa karnego w Polsce (Warszawa, 1995).

BIEDA, Justyna. 'Cele i organizacja zakładów karnych w I Rzeczypospolitej', in: Acta Universitatis Lodziensis. Folia Historica, No 94 (2015), pp. $77-9$ o.

BURBA, Domininkas. 'Mirties bausmè bajorams, XVIII a. Vilniaus pavieto pilies teismo bylų duomenimis', in: Miestas, dvaras, kaimas Lietuvos Didžiojoje Kunigaikštystëje ir Lenkijos Karalystëje XVI-XVIII a. Lokalinès istorijos problemos. Moksliniu straipsniu rinkinys, ed. R. ŠmigelskytėStukienè (Vilnius, 2018), pp. 367-393.

CZAJA, Aleksander. Między tronem, butawa a dworem petersburskim. Z dziejów Rady Nieustającej 1786-1789 (Warszawa, 1988).

DEMČENKO, Grigorij. Nakazaniie po Litovskomu Statutu v iego trekh redaktsiiakh (1529, 1566 i 1588 gg.) (Kiev, 1894).

GODEK, Sławomir. 'Kara worka w prawie dawnej Rzeczypospolitej', in: Contra leges et bonos mores. Przestępstwa obyczajowe $w$ starożytnej Grecji i Rzymie, ed. H. Kowalski, M. Kuryłowicz (Lublin, 2005), pp. 91-10o.

GODEK, Sławomir. 'O prawie i sądach w guberniach białoruskich $\mathrm{w}$ świetle aktów władz rosyjskich z 1772 roku', in: Zeszyty Prawnicze Uniwersytetu Kardynata Stefana Wyszyńskiego, t. 10, z. 1 (2010), pp. 173-19o.

KAMLER, Marcin. Przemoc między szlachta sieradzka w XVII wieku. Opis zjawiska (Warszawa, 2011).

LITYŃSKI, Adam. 'Problem kary śmierci w Polsce 1764-1794. Z badań nad historią polskiej myśli prawniczej', in: Czasopismo Prawno-Historyczne, t. 4 O, z. 2 (1988), pp. $261-275$.

LITYŃSKI, Adam. 'Ustawy karne Sejmu czteroletniego', in: Rozważania o państwie i prawie, red. A. Lityński (Katowice, 1993), pp. 116-124.

LITYŃSKI, Adam. 'Między realizmem a utopią. Rzecz o humanitarystach oświecenia', in: Studia z historii państwa, prawa i idei, prace dedykowane profesorowi Janowi Malarczykowi, red. A. Korobowicz, H. Olszewski (Lublin, 1997), pp. 231-250. 
LITYŃSKI, Adam. 'O nowej filozofii prawa karnego w Rzeczypospolitej czasów stanisławowskich uwag kilka', in: Dyplomacja, polityka, prawo. Księga pamiątkowa ofiarowana profesorowi Henrykowi Kocójowi w siedemdziesiata rocznicę urodzin, ed. Idzi Panic (Katowice, 20o1), pp. 243-252.

LITYŃSKI, Adam. 'Myśl humanitarna w Polsce czasów Oświecenia. Prawo karne materialne', in: Między humanitaryzmem a totalitaryzmem. Studia z dziejów prawa karnego (Tychy, 2002), pp. 43-62.

MAISEL, Witold. Archeologia prawna Polski (Warszawa-Poznań, 1982).

MALEC, Jerzy. 'Walka szlachty litewskiej o zachowanie III Statutu w drugiej połowie XVIII wieku', in: Czasopismo Prawno-Historyczne, t. 44, z. 1-2 (1992), pp. 65-71.

MALINOVSKII, Joannikii. Ucheniie o prestuplenii po Litovskomu Statutu (Kiev, 1894).

MICHALSKI, Jerzy. 'Problem ius agratiandi i kary śmierci w Polsce w latach siedemdziesiątych XVIII w.', in: Czasopismo Prawno-Historyczne, t. 10, z. 1 (1958), pp. $175^{-196 .}$

MIKALAUSKAS, Antanas. Das Strafrecht der drei litauischen Statute von 1529, 1566, 1588 (Kaunas, 1937).

MIKOŁAJCZYK, Marian. 'Prawo karne materialne w ustawach sejmowych w Polsce w XVIII wieku', in: Parlamentaryzm i prawodawstwo przez wieki. Prace dedykowane Prof. Stanisławowi Ptazie w siedemdziesiata rocznicę urodzin, ed. J. Malec i W. Uruszczak (Kraków, 1999), pp. 197-2o9.

MIKOŁAJCZYK, Marian. Przestępstwo i kara w prawie miast Polski potudniowej XVI-XVIII wieku (Katowice, 1998).

MONIUSZKO, Adam. 'Przestępstwa przeciw życiu i zdrowiu przed płockim sądem ziemskim pod koniec XVI stulecia', in: Spoteczeństwo staropolskie, t. II (Warszawa, 20o9), pp. 11-39.

RAUDELIŪNAS, Vytautas. 'Tortūros Lietuvos teismuose', in: Socialistine teise, No 1 (1977), pp. 44-50.

RAUDELIŪNAS, Vytautas. 'Mirties bausmė senovės Lietuvoje', in: Pozicija, No 2 (1997), pp. 8-9.

SALMONOWICZ, Stanisław. 'Lektura Dei delitti e delle pene Cezarego Beccarii (1738-1794) w dwusetlecie zgonu autora dzieła', in: $Z$ wieku Oświecenia. Studia z dziejów prawa i polityki XVIII wieku (Toruń, 2001), pp. $3^{2-48 .}$

SCHWERHOFF, Gerd. 'Gewaltkriminalität im Wandel (14.-18. Jahrhundert): Ergebnisse und Perspektiven der Forschung', in: Schweizerische Gesellschaft für Wirtschafts- und Sozialgeschichte, bd. 21 (2006), pp. 55-72.

STANKEVIČ, Adam. 'Nužudymų bylos Lietuvos Didžiosios Kunigaikštystės Vyriausiojo Tribunolo teismo praktikoje (XVIII a. antroje pusėje), in: Lietuvos Statutas ir Lietuvos Didžiosios Kunigaikštystès bajoriškoji 
visuomene. Straipsniu rinkinys, ed. I. Valikonytė, L. Steponavičienė (Vilnius, 2015), pp. 185-203.

Statut Wielkiego Xięstwa Litewskiego (Wilno, 1744).

SZAFRAŃSKI, Wojciech. Kodeks Stanistawa Augusta (Poznań, 2007).

ŠMIGELSKYTĖ-STUKIENĖ, Ramunè. 'The Modernisation of the Court System in the Grand Duchy of Lithuania: Changes to the Organisation of the Local District Courts and Regulation of Judges' Duties in 1764-1793', in: Lithuanian Historical Studies, Vol. 21 (2017), pp. 1-30.

VANSEVIČIUS, Stasys. Lietuvos Didžiosios Kunigaikštystès valstybiniaiteisiniai institutai pagal 1529, 1566 ir 1588 Lietuvos Statutus (Vilnius, 1981).

Volumina Legum, t. 6 (Petersburg, 186o).

WIĄZEK, Paweł. 'Poglądy na cele kary w Rzeczypospolitej czasów stanisławowskich', in: Acta Universitatis Wratislaviensis. Prawo, No CCCXV/2 (2013), pp. 33-50.

ZAKRZEWSKI, Andrzej. B. 'Naiwność czy taktyka? Uzasadnianie prób unifikacji prawa litewskiego i koronnego XVI-XVIII wieku', in: Lietuvos Statutas ir Lietuvos Didžiosios Kunigaikštystès bajoriškoji visuomenè. Straipsniu rinkinys, ed. I. Valikonytė, L. Steponavičienė (Vilnius, 2015), pp. $75^{-83}$.

ZAKRZEWSKI, Andrzej. B. 'Ochrona zdrowia i życia w prawie Wielkiego Księstwa Litewskiego w XVI-XVIII wieku', in: Życie i zdrowie cztowieka $w$ tradycji i kulturze polskiej. Materiaty konferencji „Problematyka życia i zdrowia $w$ tradycji i kulturze polskiej, Warszawa, 16 października 2003, ed. W. Bołoz i E. Wolnicz-Pawłowska (Warszawa, 2004), pp. 37-52.

ZAKRZEWSKI, Andrzej. B. 'O kulturze prawnej Wielkiego Księstwa Litewskiego XVI-XVIII wieku - uwagi wstępne', in: Kultura i języki Wielkiego Księstwa Litewskiego, ed. M. T. Lizisowa (Kraków, 2005), pp. 33-63.

ZARZYCKI, Wacław. 'Więziennictwo czasów stanisławowskich', in: Problemy praworządności, No 8-9 (1985), pp. 112-119.

ZDRÓJKOWSKI, Zbigniew. 'Nieznane litewskie prospekty karne Józefa Weyssenhoffa z 1792 r. (Nowoodnalezione materiały do dziejów kodyfikacji Stanisława Augusta)', in: Czasopismo Prawno-Historyczne, t. 10, z. 1 (1958), pp. 91-123.

ZUJIENE, Gitana. 'The Death Penalty in Magdeburgian Cities of the Grand Duchy of Lithuania in the Late 16th and early 17th Century', in: Lithuanian Historical Studies, Vol. 19 (2014), pp. 83-110.

ZUJIENE, Gitana. 'Mirties bausmė Žemaičiu pilies teisme XVI-XVII a. I pusèje', in: Lituanistica, t. 61, No 2 (2015), pp. 115-127.

ZUJIENĖ, Gitana. 'Mirties bausmė Lietuvos Didžiosios Kunigaikštystės bajoriškos teisės aktuose (XV-XVI a.)', in: Lietuvos istorijos metraštis. 2015/2 (Vilnius, 2016), pp. 5-32. 


\section{BAUSMIŲ TAIKYMAS ŽUDIKAMS LIETUVOS DIDŽIOSIOS KUNIGAIKŠTYSTĖS BAJORŲ TEISMŲ PRAKTIKOJE (XVIII A. ANTROJE PUSĖJE)}

Santrauka

\section{ADAM STANKEVIČ}

Straipsnyje tiriamos bausmès, kurias Lietuvos Didžiosios Kunigaikštystės bajorų teismai, sprendę XVIII a. antroje pusėje nužudymų bylas kaip pirmos instancijos teismai, taikè žudikams. Siekiama nustatyti tokiose bylose taikytų bausmių katalogą bei bausmių taikymo tendencijas atsižvelgiant ị tai, kiek jie atitiko tuo metu galiojusias teisės normas, ir ieškant teisės humanizavimo reiškinių. Ištyrus 184 nuosprendžius nustatyta, kad tyčinio nužudymo atvejais bajorų teismai dažniausiai skirdavo įstatymuose numatytą mirties bausmę. Išimtys čia darytos tik bajorų luomo asmenims, kuriems vietoj mirties bausmès kartais būdavo skiriamos žemutinio arba aukštutinio bokšto bausmès, įstatymų numatytos taikyti už kitus nusikaltimus. Tuo pat metu buvo vengiama kvalifikuotų mirties bausmės vykdymo būdų. Iš kvalifikuotų bausmių taikytas tik ketvirčiavimas, dažniausiai skiriamas nuteistiems menamo nusikaltimo - ritualinio nužudymo ir kai kuriose apiplèšimo bylose. Alternatyvios bausmès buvo epizodinès, pritaikytos nedideliam nuteistujų skaičiui: Apšvietos filosofų rekomenduojamos kalejjimo bausmès buvo skirtos tik 5,3 proc. nuteistujų nužudymo bylose. Jų taikymas daugumoje atvejų buvo susijęs su $1782 \mathrm{~m}$. Nuolatinès Tarybos universalo pasirodymu. Tokiu būdu tyrimas atskleidė Lietuvos Didžiosios Kunigaikštystès bajorijos luomo konservatyvumą, pastangas ir toliau vadovautis griežta Trečiojo Lietuvos Statuto teise. Tikètina, jog tokią praktiką galëjo lemti ir prasta penitenciarinès sistemos būklè, nes Lietuvos Didžiojoje Kunigaikštystėje tuo metu nebuvo nẻ vieno viešo kalẻjimo, kuriame būtų galima atlikti ilgalaikę kalinimo bausmę. 